\title{
Performance of Maitris in Delivering Veterinary Services in Chhattisgarh
}

\author{
K. Chandraker, B.C. Das ${ }^{*}$, P. Swain, K. Shweta and D.P. Swain \\ Department of Veterinary and A H Extension, College of Veterinary Science and Animal \\ Husbandry, OUAT, Bhubaneswar-751003, Odisha, India \\ *Corresponding author
}

\section{A B S T R A C T}

\begin{tabular}{|l|}
\hline Ke y w or d s \\
$\begin{array}{l}\text { Maitris, Performances, } \\
\text { Breeding, Healthcare, } \\
\text { Extension }\end{array}$ \\
\hline Article Info \\
\hline $\begin{array}{l}\text { Accepted: } \\
12 \text { September } 2018 \\
\text { Available Online: } \\
\text { 10 October } 2018\end{array}$ \\
\hline
\end{tabular}

\section{Introduction}

Chhattisgarh farming system is dominated by small and landless farmers who besides agriculture heavily depend on livestock for their livelihood. The state is bestowed with large number of livestock across the species but their productivity level is very low.

In the last two to three decades, it has been observed that the contribution of agriculture sector to gross domestic product (GDP) has been in declining trend whereas the contribution from livestock sector has been increasing. Unfortunately, the role of livestock sector in supporting the livelihood of poor people and that it could be a tool for social and economic empowerment, by and large, has not been fully realised despite the fact that livestock sector supports the livelihood of 200 million of rural poor (Pradhan, T.K. 2014). Incidentally, majority of livestock owners, as in India and Chhattisgarh, are small and marginal farmers or even the landless who owns about 80 per cent of the total livestock population in a mixed farming system and continue to earn their livelihood from this occupation.

The livestock wealth of Chhattisgarh is impressive in numbers across all species, constituting a natural resource base with immense livelihood implications, even though productivity levels are very low. This sector is a major contributor to rural employment next to agriculture. Provision of adequate livestock service is a prerequisite for increasing the production potentiality of livestock. Outline 
dispensaries and AI sub centres operated under the Livestock Development Department under Government of Chhattisgarh are the main source of veterinary services to all categories of livestock owners. The above institutions mostly provide curative health services, vaccination, artificial insemination and limited extension services.

In order to supplement the effort of the livestock development department to provide veterinary services to livestock owners of Chhattisgarh, Government of Chhattisgarh has introduced various private partners in the service delivery system. The private players like BAIF and JK Trusthave been providing Artificial Insemination (AI) and Veterinary First Aid (VFA) services in the rural areas. Besides, Government of Chhattisgarh through National Project on Cattle and Buffalo Breeding (NPCBB) project has developed private AI workers named as Multipurpose Artificial Insemination Technician in Rural India (Maitris) in Chhattisgarh to provide AI services, vaccination, VFA at door step and also motivate farmers for genetic up-gradation of cattle and buffalo.

Since last 11 to 12 years, they have been providing services in the rural areas with active cooperation and guidance of the veterinary department.

In spite of the best effort of the Chhattisgarh Government to retain them in service, many of them are not showing much interest to continue in the profession and are periodically opting out. The probable causes could be that either they are not getting adequate support from the department or not getting enough income from the profession or not competent in delivering various services to the livestock farmers. The present investigation was carried out to ascertain the performance level of Maitris as perceived by veterinarians of the state.

\section{Materials and Methods}

Four districts viz. Balodabazar, Dhamtari, Gariyaband and Mahasamund of Raipur Division of Chhattisgarh State was selected purposively for the study due to large population of livestock, good track record of A.I done and large number of Maitris working inthese districts. From each district, 25 Maitris were selected randomly and in total 100 Maitris were selected as respondents of the study.

Besides, 40 veterinary officials, 10 from each District were also selected to study their perception towards the performance of Maitris in delivering livestock services. The perception of veterinarians towards the performance of Maitris in delivering veterinary services in the field was assessed with the help of 7 statements each related to breeding services, healthcare and management services and extension services which were validated by experts from Veterinary College and Animal Husbandry Department. Responses of the respondents were recorded against each statement with the help of 5point continuum scale starting from strongly Agree to Strongly Disagree. Simple statistical tool like percentage was employed to draw the meaningful inferences from the data.

\section{Results and Discussion}

\section{Performance of Maitris as perceived by Veterinarians}

\section{Performance of Maitris related to breeding services as perceived by veterinarians}

To assess the performance of the Maitris related to breeding services from veterinary officials' point of view, seven questions pertinent to the field were asked to the veterinary officers of the concerned areas. The responses of the veterinary officers are 
compiled and presented in Table 1 reveals that $70 \%$ of veterinary officers were highly satisfied with therespondents in respect to their AI target achievement and rest $30 \%$ are satisfied for the same.

Similarly, when asked about common heat symptoms, $75 \%$ veterinarians said that they are highly satisfied with the knowledge of respondents regarding the common heat symptoms of cattle and buffaloes, where as $12.5 \%$ and $12.5 \%$ of veterinarians expressed their opinion as satisfactory and good respectively.

$75 \%$ of veterinarians said that the performance of respondents in conducting AI is highly satisfactory while, $12.5 \%$ said it as satisfactory and rest $12.5 \%$ veterinarians rated the same as good. When veterinarians were asked on assistance of respondents in gynaecological disorders, $62.5 \%$ rated them poor, $25 \%$ rated them average and only $12.5 \%$ rated as good. $80 \%$ of veterinarians were highly satisfied, $12.5 \%$ were satisfied and $7.5 \%$ rated as good to the idea of respondents in different breed characteristics. $45 \%$ of the veterinarians expressed that the performance of Maitris in managing heifer and pregnant cows is highly satisfactory followed by $45 \%$ and $10 \%$ of the veterinarians as satisfactory and good. Most of the veterinary doctors were not satisfied with pregnancy diagnosis skills of respondents.

$52.5 \%$ veterinary doctors rated poor, and $42.5 \%$ rated average to the pregnancy diagnosis. This indicates that most of the respondents are very poor and mostly unable to detect pregnancy and its stages in pregnant animals. Similar types of findings have been reported by various authors in their studies of para-veterinarians providing livestock health services in the rural areas (Ahuja, et al., (2003); Rajashree, B and Subramanina, R (2003); Kathiravan, G et al., (2007); Bardhan, D (2010); Swain, D P and Das B C (2016)).
Performance of Maitris related to healthcare and general management services as perceived by veterinarians

The opinion of veterinarians of Mahasamund, Gariyaband, Dhamtari and Balodabazar districts of Chhattisgarh on Maitris with respect to their knowledge and activity related to healthcare and management services is presented in Table 2. The analysis revealed that $62.5 \%$ of the veterinarians were highly satisfied where as $25 \%$ were satisfied with the respondents in their skills of vaccination and deworming of the animals. In relation to performance of respondents on census and other survey work, $87.5 \%$ of veterinarians were highly satisfied whereas $10.00 \%$ were satisfied with their activities. $75 \%$ of veterinarians were highly satisfied where as $12.5 \%$ were satisfied with respondents in their efficiency in providing first-aid services. During natural disasters, the activities of the respondents in selected district of Chhattisgarh were rated highly satisfactory by $52.5 \%$ of veterinarians, satisfactory by $25 \%$ and good by $22.5 \%$. When it comes to day to day dispensary activities by Maitris, $37.5 \%$ veterinarians rated respondents activity as average for the same. Most of the veterinarians $(90 \%)$ rated the respondent's involvement in report return and record maintenances is highly satisfactory. Similar findings were reported by Sastry NSR and Raju SR. (2005) in thier study of paraveterinarians in Andhra Pradesh and Swain and Das (2016) in their study on Gomitras in Odisha.

\section{Performance of Maitris related to extension services as perceived by veterinarians}

The analysis of the data related to the perception of veterinary officials towards the performance of Maitris in delivering extension services presented in Table 3 reveals that the performance of Maitris in conducting village 
meeting is perceived by $50 \%$ of veterinarians as satisfactory followed by $25 \%$ and $20 \%$ of veterinarians as good and average. Perception of veterinarians towards Maitris in creating awareness about the various government programmes was found satisfactory by $50 \%$ followed $12.5 \%$ and $37.5 \%$ as good and average.

Table.1 Performance of Maitris related to Breeding Services $(\mathrm{n}=40)$

\begin{tabular}{|c|c|c|c|c|c|c|}
\hline \multirow{3}{*}{$\begin{array}{l}\text { Sl. } \\
\text { No. }\end{array}$} & \multirow[t]{3}{*}{ Statements } & \multicolumn{5}{|c|}{ Extent of opinion } \\
\hline & & HS & $\mathbf{S}$ & $\mathbf{G}$ & A & $\mathbf{P}$ \\
\hline & & $\begin{array}{l}\text { No. } \\
(\%)\end{array}$ & $\begin{array}{l}\text { No. } \\
(\%)\end{array}$ & $\begin{array}{l}\text { No. } \\
(\%)\end{array}$ & $\begin{array}{l}\text { No. } \\
(\%)\end{array}$ & $\begin{array}{l}\text { No. } \\
(\%)\end{array}$ \\
\hline 1 & Achieves the A.I target & $\begin{array}{c}28 \\
(70)\end{array}$ & $\begin{array}{c}12 \\
(30)\end{array}$ & $\begin{array}{c}0 \\
(0.00)\end{array}$ & $\begin{array}{c}0 \\
(0.00)\end{array}$ & $\begin{array}{c}0 \\
(0.00)\end{array}$ \\
\hline 2 & Knows about the common heat symptoms & $\begin{array}{c}30 \\
(75)\end{array}$ & $\begin{array}{c}5 \\
(12.5)\end{array}$ & $\begin{array}{c}5 \\
(12.5)\end{array}$ & $\begin{array}{c}0 \\
(0.00)\end{array}$ & $\begin{array}{c}0 \\
(0.00)\end{array}$ \\
\hline 3 & Performance of Maitris in conducting AI & $\begin{array}{c}30 \\
(75)\end{array}$ & $\begin{array}{c}5 \\
(12.5)\end{array}$ & $\begin{array}{c}5 \\
(12.5)\end{array}$ & $\begin{array}{c}0 \\
(0.00)\end{array}$ & $\begin{array}{c}0 \\
(0.00)\end{array}$ \\
\hline 4 & Assist you in gynaecological disorder cases & $\begin{array}{c}0 \\
(0.00)\end{array}$ & $\begin{array}{c}0 \\
(0.00)\end{array}$ & $\begin{array}{c}5 \\
(12.5)\end{array}$ & $\begin{array}{c}10 \\
(25)\end{array}$ & $\begin{array}{c}25 \\
(62.5)\end{array}$ \\
\hline 5 & Idea about different breed characteristics & $\begin{array}{c}32 \\
(80)\end{array}$ & $\begin{array}{c}5 \\
(12.5)\end{array}$ & $\begin{array}{c}3 \\
(7.5)\end{array}$ & $\begin{array}{c}0 \\
(0.00)\end{array}$ & $\begin{array}{c}0 \\
(0.00)\end{array}$ \\
\hline 6 & Management of heifer and pregnant cow & $\begin{array}{c}18 \\
(45)\end{array}$ & $\begin{array}{c}18 \\
(45)\end{array}$ & $\begin{array}{c}4 \\
(10)\end{array}$ & $\begin{array}{c}0 \\
(0.00)\end{array}$ & $\begin{array}{c}0 \\
(0.00)\end{array}$ \\
\hline 7 & Pregnancy diagnosis & $\begin{array}{c}0 \\
(0.00)\end{array}$ & $\begin{array}{c}0 \\
(0.00)\end{array}$ & $\begin{array}{c}2 \\
(5)\end{array}$ & $\begin{array}{c}17 \\
(42.5)\end{array}$ & $\begin{array}{c}21 \\
(52.5)\end{array}$ \\
\hline
\end{tabular}

(HS: Highly Satisfactory, S: Satisfactory, G: Good, A: Average and P: Poor)

Table.2 Performance of Maitris related to Healthcare and General Management ( $\mathrm{n}=40)$

\begin{tabular}{|c|c|c|c|c|c|c|}
\hline \multirow{3}{*}{$\begin{array}{l}\text { Sl. } \\
\text { No. }\end{array}$} & \multirow[t]{3}{*}{ Statements } & \multicolumn{5}{|c|}{ Extent of opinion } \\
\hline & & HS & $\mathbf{S}$ & G & A & $\mathbf{P}$ \\
\hline & & $\begin{array}{l}\text { No. } \\
(\%)\end{array}$ & $\begin{array}{l}\text { No. } \\
(\%)\end{array}$ & $\begin{array}{l}\text { No. } \\
(\%)\end{array}$ & $\begin{array}{l}\text { No. } \\
(\%)\end{array}$ & $\begin{array}{l}\text { No. } \\
(\%)\end{array}$ \\
\hline 1 & Vaccination of the animal & $\begin{array}{c}25 \\
(62.5)\end{array}$ & $\begin{array}{l}10 \\
(25)\end{array}$ & $\begin{array}{c}5 \\
(12.5)\end{array}$ & $\begin{array}{c}0 \\
(0.00)\end{array}$ & $\begin{array}{c}0 \\
(0.00)\end{array}$ \\
\hline 2 & Deworming of animal & $\begin{array}{c}30 \\
(75)\end{array}$ & $\begin{array}{l}10 \\
(25)\end{array}$ & $\begin{array}{c}0 \\
(0.00)\end{array}$ & $\begin{array}{c}0 \\
(0.00)\end{array}$ & $\begin{array}{c}0 \\
(0.00)\end{array}$ \\
\hline 3 & $\begin{array}{l}\text { Performance on census and other survey } \\
\text { work }\end{array}$ & $\begin{array}{c}35 \\
(87.5)\end{array}$ & $\begin{array}{c}4 \\
(10)\end{array}$ & $\begin{array}{c}1 \\
(2.5)\end{array}$ & $\begin{array}{c}0 \\
(0.00)\end{array}$ & $\begin{array}{c}0 \\
(0.00)\end{array}$ \\
\hline 4 & Efficiency in providing first-aid services & $\begin{array}{c}30 \\
(75)\end{array}$ & $\begin{array}{c}5 \\
(12.5)\end{array}$ & $\begin{array}{c}5 \\
(12.5)\end{array}$ & $\begin{array}{c}0 \\
(0.00)\end{array}$ & $\begin{array}{c}0 \\
(0.00)\end{array}$ \\
\hline 5 & Activities during natural disaster & $\begin{array}{c}21 \\
(52.5)\end{array}$ & $\begin{array}{c}10 \\
(25)\end{array}$ & $\begin{array}{c}9 \\
(22.5)\end{array}$ & $\begin{array}{c}0 \\
(0.00)\end{array}$ & $\begin{array}{c}0 \\
(0.00)\end{array}$ \\
\hline 6 & $\begin{array}{l}\text { Helps in day today management in } \\
\text { dispensary }\end{array}$ & $\begin{array}{c}0 \\
(0.00)\end{array}$ & $\begin{array}{c}10 \\
(25)\end{array}$ & $\begin{array}{c}10 \\
(25)\end{array}$ & $\begin{array}{c}15 \\
(37.5)\end{array}$ & $\begin{array}{c}5 \\
(12.5)\end{array}$ \\
\hline 7 & Report return and record maintenances & $\begin{array}{c}36 \\
(90)\end{array}$ & $\begin{array}{c}2 \\
(5)\end{array}$ & $\begin{array}{c}2 \\
(5)\end{array}$ & $\begin{array}{c}0 \\
(0.00)\end{array}$ & $\begin{array}{c}0 \\
(0.00)\end{array}$ \\
\hline
\end{tabular}


Table.3 Performance of Maitris related to Extension Services ( $\mathrm{n}=40)$

\begin{tabular}{|c|c|c|c|c|c|c|}
\hline \multirow{3}{*}{$\begin{array}{l}\text { Sl. } \\
\text { No. }\end{array}$} & \multirow[t]{3}{*}{ Statements } & \multicolumn{5}{|c|}{ Extent of opinion } \\
\hline & & HS & $\mathbf{S}$ & G & $\mathbf{A}$ & $\mathbf{P}$ \\
\hline & & $\begin{array}{l}\text { No. } \\
(\%)\end{array}$ & $\begin{array}{l}\text { No. } \\
(\%)\end{array}$ & $\begin{array}{l}\text { No. } \\
(\%)\end{array}$ & $\begin{array}{l}\text { No. } \\
(\%)\end{array}$ & $\begin{array}{l}\text { No. } \\
(\%)\end{array}$ \\
\hline 1 & Conducting village meeting & $\begin{array}{c}0 \\
(0.00)\end{array}$ & $\begin{array}{c}20 \\
(50)\end{array}$ & $\begin{array}{c}10 \\
(25)\end{array}$ & $\begin{array}{c}8 \\
(20)\end{array}$ & $\begin{array}{c}2 \\
(5)\end{array}$ \\
\hline 2 & $\begin{array}{l}\text { Making farmers aware about } \\
\text { government programmes }\end{array}$ & $\begin{array}{c}0 \\
(0.00)\end{array}$ & $\begin{array}{c}20 \\
(50)\end{array}$ & $\begin{array}{c}5 \\
(12.5)\end{array}$ & $\begin{array}{c}15 \\
(37.5)\end{array}$ & $\begin{array}{c}0 \\
(0.00)\end{array}$ \\
\hline 3 & $\begin{array}{l}\text { Attending treatment and vaccination } \\
\text { camp }\end{array}$ & $\begin{array}{c}11 \\
(27.5)\end{array}$ & $\begin{array}{c}19 \\
(47.5)\end{array}$ & $\begin{array}{c}5 \\
(12.5)\end{array}$ & $\begin{array}{c}5 \\
(12.5)\end{array}$ & $\begin{array}{c}0 \\
(0.00)\end{array}$ \\
\hline 4 & Assisting in MVU work & $\begin{array}{c}0 \\
(0.00)\end{array}$ & $\begin{array}{c}0 \\
(0.00)\end{array}$ & $\begin{array}{c}0 \\
(0.00)\end{array}$ & $\begin{array}{c}5 \\
(12.5)\end{array}$ & $\begin{array}{c}35 \\
(87.5)\end{array}$ \\
\hline 5 & Providing services in remote area & $\begin{array}{c}31 \\
(77.5)\end{array}$ & $\begin{array}{c}9 \\
(22.5)\end{array}$ & $\begin{array}{c}0 \\
(0.00)\end{array}$ & $\begin{array}{c}0 \\
(0.00)\end{array}$ & $\begin{array}{c}0 \\
(0.00)\end{array}$ \\
\hline 6 & $\begin{array}{l}\text { Attends the training programmes at } \\
\text { various level }\end{array}$ & $\begin{array}{c}5 \\
(12.5)\end{array}$ & $\begin{array}{c}5 \\
(12.5)\end{array}$ & $\begin{array}{c}20 \\
(50)\end{array}$ & $\begin{array}{c}10 \\
(25)\end{array}$ & $\begin{array}{c}0 \\
(0.00)\end{array}$ \\
\hline 7 & $\begin{array}{l}\text { Helps in identification of beneficiaries for } \\
\text { different programmes }\end{array}$ & $\begin{array}{c}5 \\
(12.5)\end{array}$ & $\begin{array}{c}30 \\
(75)\end{array}$ & $\begin{array}{c}5 \\
(12.5)\end{array}$ & $\begin{array}{c}0 \\
(0.00)\end{array}$ & $\begin{array}{c}0 \\
(0.00)\end{array}$ \\
\hline
\end{tabular}

Performance of the Maitris in attending treatment and vaccination programmes is perceived as satisfactory by $47.5 \%$ of the veterinarians whereas $27.5 \%$ of the veterinarians perceive the performance as highly satisfactory. Most of the veterinarians rated the activities of respondents in assisting Mobile Veterinary Unit (MVU) work as poor $(87.5 \%)$. Whereas most of the veterinarians $(77.5 \%)$ rated the respondents as highly satisfactory in the way they are providing services in remote areas of selected districts.

Similarly, most of the veterinarians rated the respondents either good $(50 \%)$ or average $(25 \%)$ in attending the training programmes at various levels. In relation to helping in identification of beneficiaries for different programmes, most of the respondents $(75 \%)$ were rated satisfactory by veterinary doctors of the concerned areas. Similar types of findings were reported by Sangameswaran and Sunita (2016) in their study in Salem District of Tamil Nadu and Swain and Das (2016) in Odisha.

\section{References}

Ahuja V, McConnel KE, Umali-Deinenger D and DeHaan C. 2003. Is the poor willing to pay for livestock services? Evidence from rural India, IndianJournal of Agricultural Economics, 58 (1): 84-97.

Bardhan D. 2010. Factors influencing farmers' willingness to pay for animal health services and preference for private veterinary practitioners, Indian Journal of Animal Sciences, 80(8):790797.

Husbandry Services in Jagatsinghpur District of Odisha. Unpublished thesis, submitted to Orissa University of Agriculture and Technology (OUAT).

Kathiravan G, Thirunavukkarasu M and Michealraj P. 2007. Willingness to pay for animal health care services in small ruminants: The case of South India, Journal of Applied Sciences, 7 (16): 2361-2365. 
Maiti S. 2007. Role Performance and Job Satisfaction among Prani Bandhus of Purba Medinipur district (West Bengal).Thesis submitted to National Dairy Research institute.

Meena MS and Malik BS. 2009. Participatory identification of reproductive problems among dairy animals and constraints faced by farmers in Haryana. Indian Journal of Animal Sciences, 79(11): 1172.

Patil AP. Gawande SH. Nande M.P. and Gobade MR. 2009. Constraints faced by the dairy farmers in Nagpur District while Adopting Animal Management Practices, Veterinary world, 2(3):111112.

Rajasree B and Subramanian R. 2003. Willingness of farmers to pay for Animal Husbandry Extension Services,
Journal of Extension Education, 14:3543-3549.

Rajendran K. and Mohanty S. 2004. Dairy Co-operatives and Milk Marketing in India: Constraints and Opportunites. Journal of Food Distribution Research, 35:34-41.

Sangameswaran, R. and Sunitha P. 2016 Extent of Willingness to Pay for Dairy Husbandry Services by Milk Producers of Salem District of Tamil Nadu, Indian Res. J. Ext. Edu. 16 (3), September, 2016

Sastry NSR and Raju SR. 2005. Animal Health Workers in Andhra Pradesh: Service Delivery, Supplies, Support \& Supervision. Pro-Poor Livestock Policy Initiative, 1-6.

Swain DP and Das BC. 2016. Performance of Gomitra in delivering Veterinary and Animal

\section{How to cite this article:}

Chandraker, K., B.C. Das, P. Swain, K. Shweta and Swain, D.P. 2018. Performance of Maitris in Delivering Veterinary Services in Chhattisgarh. Int.J.Curr.Microbiol.App.Sci. 7(10): 16401645. doi: https://doi.org/10.20546/ijcmas.2018.710.186 